\title{
The Selection and Operation of Earth Moving Equipment for the Rehabilitation of Functional Soil Profiles: An updating of the UK guidance ${ }^{1}$
}

\author{
R. N. Humphries ${ }^{2}$, P. Close, and R. J. Smallshaw
}

\begin{abstract}
Soil conservation and replacement can be key factors in the sustainable use of land following mineral extraction. The earth-moving equipment and the methodology used can determine the character and functioning of the rehabilitated soil ecosystem. Practical guidance for the handling of soils by different earthmoving machines was published by the UK's Ministry of Agriculture, Fisheries and Food in 2000. It was in a form which could be understood and used by professionals and machine operators alike and has been widely used across the minerals industry for almost twenty years. Since its publication, there have been significant changes in the availability of machines, health and safety considerations, and alternative practice. As a prelude to the updating of the Guidance, to be published in early 2019, this paper considers the influence that current safe operation practice, equipment capability and planning policy might have on the choice of earth-moving equipment and methodology.
\end{abstract}

Additional Key Words: excavator, bulldozer, dump-truck, safe working, equipment capability, planning policy

${ }^{1}$ Oral paper presented at the 2018 National Meeting of the American Society of Mining and Reclamation, St Louis, MO: The Gateway to Land Reclamation, June 2- 7, 2018. Published by ASMR, 1305 Weathervane Dr, Champaign, IL 61821.

2. R. Neil Humphries, Blakemere Consultants Ltd, Dorchester DT1 3RZ, UK; Peter Close, Government Advice Team, Natural England, Newcastle upon Tyne NE4 7YH; R Julian Smallshaw, Education Officer, Institute of Quarrying, Nottingham NG9 6RZ, UK.

Journal American Society of Mining and Reclamation, 2018 Volume 7, Issue 2 pp 1-18

DOI: http://dx.doi.org/10.21000/JASMR18020001 


\section{$\underline{\text { Introduction }}$}

The conservation and replacement of soil resources in the development and closure of mineral extraction sites is usually an important part of sustainable land use whether it is for agriculture, forestry, amenity, or wildlife (e.g., McRae, 1989; Koch, 2007). Whilst the research emphasis in the last twenty years has moved from soils to primarily to biodiversity conservation, it should not be forgotten that it is the soil and its characteristics that underpin the ability to rehabilitate viable ecosystems. The machinery used and methodology in handling soils is known to have a significant bearing on the nature and functioning of the replaced soil ecosystem.

In 2000, the Ministry of Agriculture, Fisheries and Food (MAFF) published on-line and downloadable guidance for the United Kingdom (UK) mineral extractive industries and the regulating authorities on how best to operate earth-moving equipment used in the stripping, storage, and replacement of soils in mineral site development and closure (MAFF, 2000). This had followed almost thirty years of debate and joint research by the UK Government, the sand and gravel, and other sectors of the industry into the best practices and combinations of equipment for use in land restoration, and in particular that of high quality agricultural land (Anon, 1978, 1982a, 1982b, 1988a, 1988b; Fisher, 1977; McRae, 1979; Ramsay, 1986; Bacon and Humphries, 1987; Bransden, 1991). MAFF was particularly concerned with the ability to consistently restore good quality (agricultural) land and improve previously poorer land to a high quality because of development pressures on the decreasing resource. In concert, the planning authorities were concerned about the ability to achieve good standards of restoration. Coincidentally, parallel concerns were being expressed in the USA about ability to restore prime farmland after surface coal mining following the enactment of the Surface Mining Control \& Reclamation Act 1977 (Dunker et al, 1992).

Compacted replaced soil profiles were considered to be the most common and widespread legacy of restored mineral workings (Dunker et al, 1992; Land Research Associates, 2000). Whilst, there was greater potential for creating looser soil profiles over a broader spectrum of soil types and soil moisture content with the use of excavators and the loose tipping of soil from dumptrucks, than when earth-scraper or bulldozer methods were used, the expected differences in soil physical characteristics were not consistently found (Anon, 1988a 1988b, Dunker et al., 1992; Land Research Associates, 2000). This was considered to be due to the confounding effects of differences in i) soil texture and/or moisture contents at the time of the operations, ii) schemes that 
placed soils into storage rather than directly placing them, and iii) the deviation from expected practices with loose soils being traversed during the earth moving process and inadequate loosening operations for compacted soils having taken place (Bacon and Humphries, 1987; DoE 1996a, 1996b; Land Research Associates, 2000). It was particularly because of the need to ensure methods were being correctly and fully implemented more consistently that MAFF commissioned and published their Good Practice Guide for Handling Soils (Humphries Rowell Associates, 1999; MAFF, 2000).

The guidance has been readily accessible over the past 18 years and is widely used by the minerals industry and their supporting professional organisations in planning applications and environmental impact assessments, as well as in major developments (such as the high speed rail link (High Speed Two, 2017)). At site development, operational, and mine restoration/closure stages, the guidance is used by the industry's operational managers, contractors, and machine operators. It is used as a standard reference by the planning authorities and the regulatory agencies in the planning, consenting and verification processes. It is also incorporated into the Department of the Environment, Farming and Rural Affairs (Defra) downloadable procedural guidance to local government and statutory advisors for the successful restoration of mineral and waste sites to agricultural use (Defra, 2004).

Since 2000, there has been a major change in the type of earth-moving machinery used, with a move away from the use of earth-scrapers. This has largely been because of the decline in the market for large-scale stripping and long-haul work, as was the case during the major highways building programmes of the 1970s and 1980s. This decline in use coincided with the increase in availability and operating capacity in excavator and dump truck equipment by the industry and plant operating/hire companies. The result has been earth-scrapers are very rarely, if not at all, now used in the UK whereas dump-trucks, either fixed or articulated bodied, have become the universal means of transporting soil materials, and excavators and/or bulldozers are deployed for lifting and spreading soils during stripping, replacement, and soil storage (Table 1).

During this time there has been the development of an alternative bulldozer - dump-truck methodology, referred to as the peninsular or lateral heap method (McRae, 2008), for which no guidance sheet has been prepared. Responding to these changes, Defra's advisory body, Natural England, and the industry's professional body, the Institute of Quarrying, came together in 2017 
to update the Good Practice Guide for Handling Soils for release in 2019. The purpose of this paper, as a prelude to the updating of the guidance, is to consider some of the factors that are likely to determine the current choice and deployment of earth-moving machines in restoring mineral sites in the UK.

Table 1: Equipment Combinations for Soil Handling on Mineral Sites in UK

\begin{tabular}{|c|c|c|c|c|}
\hline Combination & Soil Stripping & Soil Storage & $\begin{array}{l}\text { Access/Haul- } \\
\text { road } \\
\text { Maintenance }\end{array}$ & $\begin{array}{l}\text { Soil } \\
\text { Spreading\#* }\end{array}$ \\
\hline Excavator - & 20-30 tonne & $30-40$ tonne & D6/8 bulldozer & 20-30 tonne \\
\hline Dump-truck & $\begin{array}{l}360^{\circ} \text { excavator }+ \\
20-40 \text { tonne } \\
\text { capacity } \\
\text { articulated } \\
\text { dump-truck }\end{array}$ & $\begin{array}{l}360^{\circ} \text { excavator } \\
+/- \text { D6 bulldozer }\end{array}$ & +/- Grader & $\begin{array}{l}360^{\circ} \text { excavator }+ \\
20-40 \text { tonne } \\
\text { capacity } \\
\text { articulated } \\
\text { dump-truck }\end{array}$ \\
\hline $\begin{array}{l}\text { Bulldozer - } \\
\text { Dump-truck }\end{array}$ & $\begin{array}{l}\text { D6 bulldozer }+ \\
20-30 \text { tonne } \\
360^{\circ} \text { excavator }+ \\
20-40 \text { tonne } \\
\text { capacity } \\
\text { articulated } \\
\text { dump-truck }\end{array}$ & $\begin{array}{l}30-40 \text { tonne } \\
360^{\circ} \text { excavator } \\
+/- \text { D6 bulldozer }\end{array}$ & $\begin{array}{l}\text { D6/8 bulldozer } \\
\text { +/- Grader }\end{array}$ & $\begin{array}{l}\text { D6 bulldozer + } \\
20-40 \text { tonne } \\
\text { capacity } \\
\text { articulated } \\
\text { dump-truck }\end{array}$ \\
\hline
\end{tabular}

\# where decompaction of the underlying formation/fill/'bedrock' is required this may require use of excavator or bulldozer D6/D8 with appropriate ripping- tine configuration

*stone-rake or other stone removal equipment to be provided where surface stone material is to be removed

\section{Factors Determining the Selection Equipment}

Following preliminary discussions, three factors of safe working, equipment capability, and planning and development control policies are likely to be key factors in the selection of earthmoving equipment in the UK.

\section{$\underline{\text { Safe Working }}$}

Safe working practice has come to the fore for mineral site operators, contractors, and their workers, as elsewhere, owing to the consolidation of the legal and societal responsibilities required by health and safety legislation, employment law, and acceptable practices in the workplace (HSE, 2017; QNJAC, Undated). All work now is managed by holistic risk assessment health and safety management systems that review the working environment (where topographical, ground condition risks, and equipment operational limitations are amongst the headline considerations), the safety of the equipment used (i.e., maintenance, suitability), the competency of the operators 
(i.e., training and experience), as well as a fit-for-purpose management system of controls and measures (i.e., documented policy, procedures, programmes, training and specification manuals). Here, the safeness of the environment and equipment suitability has a significant influence on the choice of equipment, and how earth-moving operations are to be organised and undertaken.

Topography, as the gradient and complexity of the land being stripped of soils and overburden prior to working and the landform on replacement of soils and backfill at time of mine closure, is one consideration of the type and operation of the machinery to be used (Humphries, 2010). The ultimate choice may be determined by the safe capability over and above the manufacturer's indicative limitations on the equipment in terms of travelling over the ground surface and in carrying out the work. However, some indicative operational and safety limitations are given in Table 2.

Table 2: Slope (gradient) Limits on Equipment Operation\#

\begin{tabular}{|l|l|l|}
\hline Equipment Type & Activity & Maximum Slope Limit\# \\
\hline \multirow{3}{*}{$\begin{array}{l}\text { Articulated Dump-Truck } \\
\text { loaded) }\end{array}$} & Travel up/down slope & $1: 3.5(30 \%)$ \\
\cline { 2 - 3 } & Travel across slope & $1: 6(15 \%)$ \\
\cline { 2 - 3 } & Tipping down slope & $1: 6(15 \%)$ \\
\hline Excavator $360^{\circ}$ & Travel up/down slope & $1: 3(35 \%)$ \\
\cline { 2 - 3 } & Travel across slope & $1: 3(35 \%)$ \\
\cline { 2 - 3 } & $\begin{array}{l}\text { Digging/spreading down } \\
\text { slope }\end{array}$ & $1: 4(33 \%)$ \\
\hline Bulldozer & Travel up/down slope & $\begin{array}{l}\text { D6 1:1.6 (63\%) D8 1:2 } \\
(50 \%)\end{array}$ \\
\cline { 2 - 3 } & Travel across slope & D6 \& D8 1:4 (25\%) \\
\cline { 2 - 3 } & Pushing down slope & D6 1:2(50\%) D8 (1:2.5) \\
\hline
\end{tabular}

\# These are indicative limits for simple slopes where ground conditions fully support the machines and should not be relied upon and may differ according to specific site and ground conditions, manufacturers' recommendations, operating organisation's policy , other guidance such as QNJAC. For example, many operators will not allow loaded articulated trucks to move up/down slopes steeper than 1:6 (17\%) and across slopes of 1:10 (10\%).

As a broad generalisation (subject to other limitations), soil stripping and replacement using the excavators and dump-truck combination may be limited by the ability of the excavator to reach the soil, handle the loaded bucket load, and load a dump-truck safely on gradients steeper than 1:6 (17\%). Depending on ground conditions and landform complexity, this should enable the excavator combination to be potentially deployed for stripping of soils on the sloping ground of 'best and most versatile' agricultural land quality Grades 1 and 2, and Sub-grades 3a (i.e., land less 
steep than 1:8 (12\%) (MAFF, 1988) without terracing for the excavator and dump trucks to work safely.

Bulldozers would be expected to be able to undertake soil stripping and replacement operations safely on steeper gradients up to 1:2 (50\%), but where there is provision of less steep grades (by terracing) for the dump-trucks and the excavator to safely operate from.

Ground conditions (essentially the bearing capacity of the materials being stood upon and traversed) and the interaction with gradient may be the determining factor in the selection of equipment for safe working if 'too soft' and/or 'too wet' (without special provisions such as the placement of more competent material or laying artificial tracks).

\section{Equipment Capability}

Reach of Excavator Boom. Also involved in the decision making is the capability and effectiveness of the equipment to be used. For example, consideration of the excavator combination should include the effective working reach of the excavator boom-arm, whether it can physically reach sufficiently up/down slope to recover the soils during site development or replace soils at restoration whilst operating in a safe way. Typically, the boom-arm length of excavators used to dig and load materials (Table 1) are limited in their effective reach to 5-7m having been optimised for digging purposes and relation to the size of the machine.

Longer reach excavators are available and are usually used for specialist tasks, such as cleaning-out silt lagoons or demolition work. Whilst these increase the effective reach to $10 \mathrm{~m}$ or more, the excavator may be less stable when reaching over long slopes without a sequential development of terracing being part of the site development/restoration infrastructure. Typically, long-reach excavators are only able to operate with smaller capacity bucket sizes than standard machines, making the operation slower and less efficient. In these circumstances, the bulldozer combination may be more flexible and cost effective, and the preferred method.

Compacted Soil Profiles. Unquestionably, the occurrence and degree of compaction and smearing of soils by the machines and methodologies used differs between those not traversing and those traversing the soil surface during soil stripping, storage, and replacement. Where soil compaction is a factor in the restoration of land and relatively looser soil layers are required to achieve the 
restoration objectives, this has generally been more consistently achieved when excavators have been used to strip and replace soils (Dunker et al., 1992; Land Research Associates, 2000).

Depending on the routes taken by the component equipment (Anon, 1978; Bacon and Humphries, 1987; Dunker et al., 1992) and their compliance with recommended operating practices (see MAFF, 2000), the excavator with dump-trucks method has intrinsically a lower risk of resulting in severely compacted and smeared soil material (unless the soils are stored in mounds where the difference between bulldozer method is likely to be much less). Soil moisture content (wetness) influences the risk and degree of soil compaction and smearing of fine textured soils and the risk increases with higher moisture contents when near to and above the plastic limit (MAFF, 1982). Bulldozers working on the soil surface pushing soils to strip, grade, or to spread soils are a risk, even low ground-pressure machines which often have to traverse the ground more times to achieve the same amount of work as standard narrower-tracked units.

Where loose soils are expected, but have not materialised using excavators (often when the soil has been stored in mounds or handled when in a wet condition) or where bulldozer or other machinery has subsequently travelled over soil surfaces during soil replacement, remediation will be an essential part of the restoration process. However, the depth of loose soil required may differ according to the land-use capability, habitat, and soil conservation objectives and expectations (Humphries and McQuire, 1994). There are circumstances, such as wetlands and wet habitats that require less free draining soil profiles and compaction in the soil profile can be beneficial. Hence, the choice of equipment and methodology needs to be specific to the restoration scheme.

Effective Soil Loosening. The need for remedial action to ensure compaction is minimised is often overlooked during the restoration works, and where it is undertaken it is often inadequately performed simply because of the limited capability and effectiveness of the equipment used. Soil loosening can be potentially achieved by ripping with tines (Binns, 1983; Bacon and Humphries, 1987; Dunker et al., 1992; Moffat and Boswell, 1997; Spoor and Foot, 1998; Croton and Ainsworth, 2007; Kew et al., 2007) or digging over the compacted ground using an excavator (Moffat and McNeill, 1994; Moffat and Bending, 2000; Sinnett et al., 2006). The effectiveness of both these remedial actions is dependent on appropriate equipment and methods being used and the ground conditions (particularly soil moisture content) at the time. 
Firstly, the loosening of soil profiles will be needed wherever the spreading has been carried out with the bulldozer combination, even if low ground pressure machines have been used and even where methods such as the 'peninsular method' have involved dump-trucks running over laid soils. The loosening of excavator laid soils may also be required where the land is being entirely restored as one horizon at a time (i.e., all subsoil placed, followed by the topsoil) resulting in the lower layers of he laid soil being traversed by the excavator/bulldozer and dump trucks. The previously laid soil needs to be dug over as sequential strips using the excavator bucket or specialist stone-rake/tined buckets, or treated by bulldozer drawn tines, as would be the case for bulldozer restored soils. Activities such as destoning of excavator laid soils involving (even tracked) earthmoving or agricultural vehicles traversing the re-laid profiles are also likely to require reloosening.

Secondly, a particularly misunderstood aspect is the effective depth of soil loosening that can be achieved by tines to rip the soil profile. It is often and mistakenly assumed to be the length of the tine from the tip of the shank to the underside of the tool-bar, but this is not the case as the potential depth of the length of the tine is reduced significantly by the soil heaving during the operation. This causes the bulldozer operator to raise the tool bar thereby reducing the depth of penetration and the loosening achieved.

Thirdly, the configuration of the tines is also a consideration, as is the number and pattern of passes. Tines must be aligned with each of the bulldozer's caterpillar tracks with usually one intermediate tine. Rarely is the soil layer sufficiently loosened with one pass. This can only be achieved by adopting over-lapping passes rather than the much less effective, but commonly used, method of 'cross-ripping.'

Fourthly, where the depth of compacted soils exceeds the effective reach of the tine, then sequential loosening of the layers of soil as they are laid will be needed.

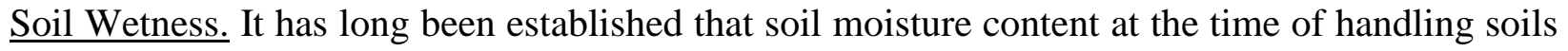
has a bearing on soil functional condition, particularly compaction and deformation of previous soil structural elements, on restoration (Duncan and Bransden, 1986; King, 1988). Where soils are dry and below their plastic limit, there has been less of a difference between the excavator and earth-scraper or bulldozer spread soils (Dunker et al., 1992; Land Research Associates, 2000). In practice, soil wetness will be a function of the site's location, soils, drainage, vegetation cover, and 
timing and duration of the operations. Whilst in some cases the timing of operations might be programmed to reduce the risk of soil compaction, in others such as poorly draining soils in relatively wetter parts of the country are unlikely to be in a dry enough condition, as are some fine textured subsoils in drier parts of the UK. The current guidance is to encourage soil handling activity between April and September (Defra, 2009). It is recognised that it may not be possible to coincide site developments with the occurrence of soils drier than their plastic limits, and whilst development control criteria involving soil moisture measurements might be imposed, a pragmatic approach is generally accepted with operations being undertaken in all but adverse weather (DoE, 1996a, 1996b; Defra, 2009). In these circumstances, the choice of equipment may be determined by the ground conditions and the ability to maintain safe working practices.

\section{Planning \& Development Control Policy}

Planning and development control policies will continue to influence the selection of earth moving equipment and methodology. The current overarching UK policy guidance for mineral development is set out in Section 13 "Facilitating the Sustainable Use of Minerals" of the National Planning Policy Framework (UK Government, 2012). The devolved UK Country Governments and their Local Planning Authorities' have the responsibility to have in place planning policies, amongst others, to ensure i) high quality restoration takes place, and ii) for 'best and most versatile' agricultural land (Agricultural Land Classification Grades 1 \& 2 and Sub-Grade 3a) and its long term potential is safe-guarded. It is also their responsibility to ensure that restoration is carried out to the highest standards by imposing appropriate planning (permit) conditions.

At the implementing local authority level, the current policies are typically set out in their Minerals Local Plans or Mineral Strategy statements. However, they provide only principles rather than detail or prescription. For example, the following statements are typical, “... measures will be taken to ensure that soil quality will be adequately protected ...' (Bournemouth, et al., 2014), "The manner in which soil materials are handled is also a key element of successful restoration, and details of the management of soils, including storage methods, timing and means of soil movements, and machinery to be used will be required" and "the land could be restored to its previous agricultural quality or better" (Leicestershire County Council, 2016), and "Where appropriate, proposals shall demonstrate the best available techniques to ensure that: a) Soil resources are retained, conserved and handled appropriately during operations and restoration, b) 
In the case of minerals development affecting the best and most versatile agricultural land, the land is capable of being restored back to best and most versatile land" (Essex County Council, 2014). It is left to the mineral operator to proffer and justify their proposed equipment and methodology, and to the planning authority and its statutory advisors (such as Natural England in England) to determine if they are appropriate and likely to achieve the necessary restoration outcome, or that other approaches are to be used before the planning application be permitted.

The core technical guidance generally cited in the local authority plans and policies comprises the Good Practice Guide for Handling Soils (MAFF, 2000), the Guidance for Successful Reclamation of Mineral and Waste Sites (Defra, 2004), and the Construction Code of Practice for the Sustainable Use of Soils on Construction Sites (Defra, 2009). However, the Defra 2004 guidance only refers to two of the three equipment combinations and methods for which good practice had been provided in the MAFF guidance (MAFF, 2000), these being the excavator-dump truck and earth-scraper (the latter now largely not used) methods of stripping and spreading of soils. The Defra 2004 guidance accepts that site conditions and timing may need the use of different equipment to the excavator-dump truck or earth-scraper methods. Here, it is up to the operator to demonstrate the need for any deviation from the MAFF (2000) methodologies. Similarly, where another equipment or methodology is proposed, it is up to the operator to demonstrate that it can deliver the required or satisfactory restoration outcomes (Defra, 2004).

Whereas the three sources of guidance are readily available on the internet, those of MAFF (2000) and Defra (2004) are now located in Defra's archive, and only the construction code (Defra, 2009) is cited on the UK Government web-site (UK Government, 2011), thereby implying that it is the primary source of guidance. However, the construction code was written specifically for construction sites and not for mineral extraction developments. It states that the preferred method of soil handling by machines is the excavator-dump truck method, however, it also says, "Alternative stripping methods that can be shown to afford the same degree of soil protection are acceptable.". Notably, it is not prescriptive and recognises that method statements devised prior to construction might need to be modified to meet specific on-site circumstances or incorporate new ideas such as the 'peninsular method' (McRae, 2008; Defra, 2009). Hence, the current published Defra guidance implies there is flexibility as to the choice of soil moving equipment. 
However, where land is of a high agricultural quality (i.e., Agricultural Land Classification Grades $1 \& 2$ and Sub-Grade 3a) planning and development control policy has a bearing on the choice of equipment. Here, the policy is to protect such land from unnecessary development, but where mineral extraction is granted (as a temporary use of the land) the policy is to promote the restoration of land with similar productivity and soil structural condition. Because, experience has shown there is a greater risk of damaging soil structure through compaction and smearing when earth moving equipment traverses the soils (Anon, 1988a, 1988b; Dunker et al., 1992; Land Research Associates, 2000), there will be a presumption by the planning authorities and their advisors that the excavator - dump truck combination should be used for soil stripping, storage and replacement and follow the published process of ensuring delivery (Defra 2004). Proposals to use other equipment and practices are conditional when it can be demonstrated to meet the same quality objectives as the preferred excavator methodology under operational conditions. For the bulldozer combination and any other variation of practice there could be stricter constraints imposed, such as limiting the timing of operations with respect to soil moisture content and soil consistency. The stipulated soil moisture contexts at stripping and during relaying with bulldozers will be lower than for the excavator combination and the operator may need to demonstrate that they can be met in practice.

Finally, other land-use policies can also have a bearing on equipment selection for nonagricultural use such as forestry. Here, it is recommended that loosely tipped soils and spreading by excavators should be the preferred method (Moffat and McNeill, 1994).

\section{Discussion and Conclusions}

The above overview established that two additional factors to that of planning policy guidelines are likely to be influential in the selection of earth-moving equipment for the restoration of mineral sites in the UK. The updating of the MAFF Guidance should have cognisance of this and where possible integrate them into the update. As a consequence, the revised guidance should be presented as a process to help the Users in its use, rather than simply stand-alone operational practices for combinations of equipment. It also needs to include developments in practice such as the 'peninsular method' for which guidance has not been prepared.

Safe Working Led Choice 
At the time the MAFF guidance was being written the choice of earth-moving equipment was being influenced by planning control policies and processes (Defra, 2004). Since then, the process of choosing earth-moving equipment has become firmly safety led and formalised as part of the operators' and contractors' safety management systems.

The choice of machines will ultimately be the responsibility of the delegated person(s) within the mineral and contractor organisation's undertaking the work. In the past, the decision making has typically been undertaken at the implementation stage(s) of the mineral development. Consequently, it has not been uncommon for different combinations and working practices to be proffered at the planning submission stage than that used at the development stage.

An outcome of the safe working led approach could be that a less than optimal methodology for soil handling and land quality restoration might result. A key addition to the updated guidance should be to set out a process whereby the safe operational matters inform the choice of equipment, methodology, and remedial measures necessary.

\section{Equipment Capability}

Preferences. In reality, cost and time taken to complete the work will also be factors determining equipment selection, as is the personal preference of the specifying organisation and individuals, and vagrancies of equipment availability. Earlier claims of differential cost and time taken between excavator and bulldozer methods have largely been dispelled as the main factors are number of dump-trucks available and length of haulage route, which is common to both excavator and bulldozer methods of soil stripping and replacement. This aspect may have simply become a matter of better matching of equipment type and capacity with the work.

For timing, economic and sometimes convenience reasons, some schemes will deploy machines being used elsewhere in the mineral extraction or processing operations, rather than bring in bespoke equipment, with a concomitant greater risk that less appropriate machinery is used. Here, the risks need to be identified, evaluated, and appropriate remedies undertaken. Such advice should be incorporated into the updated guidance.

Early Identification. Experience has shown that the actual equipment and methodology used can deviate from that specified during the environmental impact assessment process or submitted in compliance with conditions at the consent stage. Whilst Defra's archived guidance (Defra, 2004) 
draws attention to this possibility and the need to track, check, and question the intended and actual methods, the current Code (Defra, 2009) does not, thereby leaving the risk that other equipment might be used in practice and the restoration outcome might not be that expected. Advice should be included on how to ensure that the actual methods to be used are identified before the planning submission and are incorporated into it.

Performance. Where the best quality agricultural land and other land-uses requiring loose soil profiles are involved it might be expected there will be a presumption by the planning authorities and regulators for the selection of the excavator dump-truck combination, wherever they can be safely deployed. Importantly, the updated guidance needs to link any necessary remedial measures to the equipment combination used. This was an omission of the MAFF 2000 guidance. For example, if bulldozer methods are deployed, then soil loosening work will be required by default (irrespective of whether low ground-pressure machines have or have not been used) as part of the restoration process.

\section{Evidence-Base}

Of relevance is the adequacy of the supporting evidence-bases. The Defra 2004 guidance and the Defra 2009 construction code draw attention to the need to monitor in detail all stages of the submissions and implementation of the works. This is not only beneficial for the improvement in safe working practices, selection of equipment and techniques, the development of planning policies, and the improvement of restoration outcomes, it provides evidence for the support of alternatives and improved practices, besides supporting justification for the sustainable working of further mineral reserves (Humphries, 2013). Whilst this may be difficult for the planning authorities and regulators to undertake due to spending cuts in public sector, it will be for the mineral industry to take on the challenge. Here, the updated guidance could usefully set out the process for monitoring and evidence building.

\section{Acknowledgements}

We thank David Turton of Finnings Ltd (Catapillar UK) and Mike Harper of Volvo UK for providing OEM information, and John Rees and Mark Heames (Celtic Energy Ltd) for advice on safe working in practice.

\section{References}


Anon. 1978. Joint Agricultural Land Restoration Experiments: Progress Report No.1, 1974-1977 for Papercourt Farm, Ripley, Surrey and Bush Farm, Upminster, Essex. Department of the Environment, Ministry of Agriculture, Fisheries and Food, Sand and Gravel Association, London.

Anon. 1982a. Joint Agricultural Land Restoration Experiments: Progress Report No.2, 1977-1982 for Bush Farm, Upminster, Essex. Department of the Environment, Ministry of Agriculture, Fisheries and Food, Sand and Gravel Association, London.

Anon. 1982b. Joint Agricultural Land Restoration Experiments: Progress Report No.2, 1977-1982 for Papercourt Farm, Ripley, Surrey. Department of the Environment, Ministry of Agriculture, Fisheries and Food, Sand and Gravel Association, London.

Anon. 1988a. Joint Agricultural Land Restoration Experiments: Bush Farm, Upminster, Essex Final Report (Main Report) 1982-1987. Department of the Environment, Ministry of Agriculture, Fisheries and Food, Sand and Gravel Association, London.

Anon. 1988b. Joint Agricultural Land Restoration Experiments: Bush Farm, Upminster, Essex Final Report (Technical Sections) 1982-1987. Department of the Environment, Ministry of Agriculture, Fisheries and Food, Sand and Gravel Association, London.

Bacon, A. R. and R. N. Humphries. 1987. Deep ripping: A more effective and flexible method for achieving loose soil profiles. In Rainbow, A K M (ed). Advances in Mining Science \& Technology 2: Reclamation, Treatment and Utilisation of Coal Mining Wastes. Elsevier, Amsterdam pp 321-330. https://doi.org/10.1016/B978-0-444-42876-9.50030-0

Binns, W. O. 1983. Treatment of surface workings. In Research and Development Paper 132: Reclamation of Mineral Workings to Forestry. Forestry Commission, Edinburgh pp 9-16.

Bournemouth, Dorset \& Poole. 2014. Minerals Strategy. Available at https://www.dorsetforyou.gov.uk/mcs Viewed 19/10/17.

Bransden, B. E. 1991. Soil protection as a component of gravel raising. Soil Use and Management, 7, 3, pp 139-144. https://doi.org/10.1111/j.1475-2743.1991.tb00865.x 
Croton, J. T. and G. L. Ainsworth. 2007. Development of a winged tine to relieve mining-related soil compaction after bauxite mining in Western Australia. Restoration Ecology, 15, S4, pp S48-S53. https://doi.org/10.1111/j.1526-100X.2007.00292.x

Defra. 2004. Defra Guidance for Successful Reclamation of Mineral and Waste Sites. Available at http://webarchive.nationalarchives.gov.uk/20090318074806/http://www.defra.gov.uk/farm/e nvironment/land-use/reclamation/restoration/rn5.pdf Viewed 19/10/17.

Defra. 2009. Construction Code of Practice for the Sustainable Use of Soils on Construction Sites. Department for Environment, Food and Rural Affairs, London.

DoE. 1996a. The Reclamation of Mineral Workings to Agriculture. HMSO, London

DoE 1996b. Guidance on Good Practice for the Reclamation of Mineral Workings to Agriculture. HMSO, London.

Duncan, N. A. and B. E. Bransden. 1986. The effects on a restored soil caused by soil moving under different moisture contents. Applied Geography, 6, 3, pp 267-273. https://doi.org/10.1016/0143-6228(86)90006-8

Dunker, R. E., R. I. Barnhisel and R. G. Darmody (eds). 1992. Proceedings of the 1992 National Symposium on Prime Farmland Reclamation. University of Illinois at Urbana-Champaign, Illinois.

Essex County Council, 2014. Essex Minerals Local Plan. Available at https://www.essex.gov.uk/Environment\%20Planning/Planning/Minerals-Waste-PlanningTeam/Planning-Policy/minerals-developmentdocument/Documents/Essex\%20Minerals\%20Plan\%20-\%20Adopted\%20July\%202014.pdf Viewed 19/10/17.

Fisher, G. G. 1977. Preserving the fertility of soils disturbed during mineral working. In Land Reclamation Conference Papers, September 1976. Thorrock Borough Council, Essex, Great Britain pp 263-280.

High Speed Two. 2017. Phase 2a Information Paper - E19: Soil handling for land restoration. Available at 
Journal American Society of Mining and Reclamation, 2018 Vol.7, No.2

https://www.gov.uk/government/uploads/system/uploads/attachment_data/file/628465/E19_S oil_Handling_for_Land_Restoration_v1.0.pdf Viewed 19/10/17.

HSE. 2017. Health and Safety at Work etc Act 1974. Available at http://www.hse.gov.uk/legislation/hswa.htm Viewed 19/10/17.

Humphries, R. N. 2010. Landform and soil factors in habitat translocation for biological conservation and ecological restoration: A new framework and tool. In $\mathrm{H}$ R Fox and $\mathrm{H} \mathrm{M}$ Moore (eds). Restoration and Recovery: Regenerating land and communities. Whittles Publishing, Dunbeath pp 190 - 195.

Humphries, R. N. 2013. The requirement and implications of evidence-based restoration schemes in the United Kingdom. In M Tibbett, A B Fourie and C Digby (eds), Mine Closure 2013: Proceedings of the Eighth International Conference on Mine Closure, 18-20 September 2013, Cornwall, England. Australian Centre for Geomechanics, Nedlands, Western Australia pp 355 -361 .

Humphries, R. N. and G. E. McQuire. 1994. Physical criteria for the design and assessment of restoration schemes in the United Kingdom. In International Land Reclamation and Mine Drainage Conference and Third International Conference on the Abatement of acidic Drainage, Volume 3. Reclamation and Revegetation. Special Publication 06C-94, Bureau of Mines, United States Department of the Interior, Washington DC pp $232-240$. https://doi.org/10.21000/JASMR94030232

Humphries Rowell Associates. 1999. Best Practice Guidance for Soil Handling and Standards for Monitoring

Available

at

http://randd.defra.gov.uk/Default.aspx?Menu=Menu\&Module=More \&Location=None \&Com pleted=0\&ProjectID=8593\#RelatedDocuments Viewed 19/10/17.

Kew, G. A., F. C. Mengler and R. J. Gilkes. 2007. Regolith strength, water retention and implications for ripping and plant growth in bauxite mine restoration. Restoration Ecology 15, S4, pp S54-S64. https://doi.org/10.1111/j.1526-100X.2007.00293.x

King, J. A. 1988. Some physical features of soil after opencast mining, Soil Use and Management, 4, 1, pp 23-30. https://doi.org/10.1111/j.1475-2743.1988.tb00732.x 
Koch, J. 2007. Alcoa's mining and restoration process in South Western Australia. Restoration Ecology, 15, 4 (supplement), pp S11-S16.

Land Research Associates. 2000. Report 313/50: Evaluation of Mineral Sites Restored to Agriculture. MAFF, London.

Leicestershire County Council. 2016. Minerals Local Plan. Available at https://www.leicestershire.gov.uk/environment-and-planning/planning/minerals-and-wastelocal-plan/policy-documents Viewed 19/10/17.

MAFF. 1982. Reference Book 441: Techniques for measuring soil physical properties. HMSO, London.

MAFF. 1988. Agricultural Land Classification of England \& Wales. Ministry of Agriculture, Fisheries \& Food, Alnwick.

MAFF. 2000. Good practice guide for handling soils. Available at http://webarchive.nationalarchives.gov.uk/20090317221756/http://www.defra.gov.uk/farm/e nvironment/land-use/soilguid/index.htm Viewed 19/10/17.

Moffat, A. J. and R. C. Boswell. 1997. The effectiveness of cultivation using the winged tine on restored sand and gravel workings. Soil and Tillage Research 40, (1-2), pp 111-124. https://doi.org/10.1016/S0167-1987(96)01074-4

Moffat, A. J. and N. A. D. Bending. 2000. Replacement of soil and soil forming materials by loose tipping in reclamation to woodland. Soil Use and Management 16, 2, pp 75-81. https://doi.org/10.1111/j.1475-2743.2000.tb00178.x

Moffat, A. and J. McNeill. 1994. Bulletin 110: Reclaiming Disturbed Land to Forestry. HMSO, London.

McRae, S. G. 1979. The agricultural restoration of sand and gravel quarries in Great Britain. Reclamation Review, 2, pp 133-141.

McRae, S. G. 1989. The restoration of mineral workings in Britain - a review. Soil Use and Management, 5, 3, pp 135-142. https://doi.org/10.1111/j.1475-2743.1989.tb00774.x 
McRae, S. G. 2008. Soil Handling - Modified Loose Tipping Procedure for Soil Replacement. Available at: $\quad$ http://planning.cambridgeshire.gov.uk/swift/MediaTemp/416951950961605.pdf viewed 14/02/17.

QNJAC. Undated. Essential Health and Safety Guidance foe quarries. Available at http://www.qnjac.co.uk Viewed 17/02/18.

Ramsay, W. J H. 1986. Bulk soil handling foe quarry restoration. Soil Use and Management, 2, 1, pp 30-39. https://doi.org/10.1111/j.1475-2743.1986.tb00675.x

Sinnett, D., J. Poole, and T. R. Hutchinson. 2006. The efficiency of three techniques to alleviate soil compaction at a restored sand and gravel quarry. Soil Use and Management 22, 4, pp 362371. https://doi.org/10.1111/j.1475-2743.2006.00053.x

Spoor, G. and K. Foot. 1998. Soil compaction alleviation on restored sites. In H. R. Fox, H. M. Moore and A. D. McIntosh (eds). Land Reclamation: Achieving Sustainable Benefits. A.A. Balkema, Rotterdam pp 277-286.

UK Government. 2011. Code of practice for the sustainable use of soils on construction sites. Available at https://www.gov.uk/government/publications/code-of-practice-for-the-

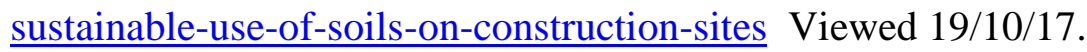

UK Government. 2012. National Planning Policy Framework. Available at https://www.gov.uk/government/publications/national-planning-policy-framework--2 Viewed 19/10/17. 